\title{
Abies sibirica Leaf Oil
}

National Cancer Institute

\section{Source}

National Cancer Institute. Abies sibirica Leaf Oil. NCI Thesaurus. Code C107256.

The essential oil of Abies sibirica. Siberian fir oil is used in aromatherapy and perfumes. 